\title{
OXYGEN INCREASE ON MODIFIED PADDLE WHEEL OF MARINE AND FISHERIES POLYTECHNIC OF SIDOARJO
}

\author{
Nasuki*, Widodo A., Sutrisno, Setyastuti T.A. \\ Fisheries Mechanization Program, Polytechnic Marine and Fisheries, Indonesia \\ *E-mail: caknash@yahoo.co.id
}

\begin{abstract}
One type of aeration device is a paddle wheel which is the most common aerator used for aquaculture ponds (Wyban et al. 1989; Moore \& Whitis 1999; Laksitanonta et al., 2003). The aeration rate is influenced by the surface area of water and air contact, the difference of oxygen concentration, coating film coefficient and turbulence (Boyd 1998) The geometry, and speed of the spin mill affect aeration performance (Peterson \& Walker 2002; Moulick et al., 2002). Aerator performance is an important factor in the selection and use of aerators as they relate to investment and operational costs, so that the development of aerator design and improved operating performance is still possible to do. The purpose of this research is to know the comparison of paddle wheel performance result of modified design versus paddle wheels manufacturer. The research was designed with 2 (two) different types of paddle wheel which is the treatment of 1 (one) paddle wheel from the modified of construction design with a power of $0.37 \mathrm{kwh}^{-1} 0.5 \mathrm{hp}$ and the treatment of 2 (two) artificial paddle wheel from manufacturer with $0.78 \mathrm{kwh}^{-1} 1 \mathrm{hp}$. Statistical analysis use T-test. The results of research is modified Paddle wheel (Treatment 1) was increased of $D O=2.56 \mathrm{ppm}$; Coverage area $=418929,6 \mathrm{~cm}^{2}$; diameter bursts $=132.2 \mathrm{~cm}$. Conventional paddle wheel performance (treatment 2) was increased of DO $=2.54 \mathrm{ppm}$; Coverage area $=41983,8 \mathrm{~cm}^{2}$; The diameter of the bursts is $130.2 \mathrm{~cm}$. The t test results (statistic) on all variables showed no significant different $(p=0.595)$. This means the performance of the modified paddle wheel with $0.37 \mathrm{KWh}^{-1} 0.5 \mathrm{hp}$ one phase is the same as the conventional paddle wheel performance with $0.78 \mathrm{KWh}^{-1} 1 \mathrm{hp}$ two phase power but there are energy saving $0.41 \mathrm{KWh}^{-1}$.
\end{abstract}

\section{KEY WORDS}

Paddle wheel, coverage area, aerator, water.

Paddle wheel is one of the tools in fish ponds that serve to move of water. The existence of paddle wheel in the pond is expected to help and anticipate the occurrence of oxygen deprivation and anticipate the difference that is quite striking between layers of pond water. In addition, paddle wheel is used to increase the levels of DO, through paddle wheels, can stabilize the surrounding biological processes, and reducing the growth of harmful algae.

Some models of aerators, such as Taiwan aerators, are available on the market and are widely used due to their relatively low cost, light weight and corrosion resistance, but this aerator has low aeration efficiency (Wyban 1989; Laksitanonta, 2003). Taiwan's aerators have SAE (standard aeration efficiency) value of $1,063 \mathrm{~kg} \mathrm{O}_{2} \mathrm{~kW} \mathrm{~h}^{-1}$ (Peterson \& Walker 2002). The design aerator of Bhuyar et al (2009) has SAE 2,269 $\mathrm{kg} \mathrm{O}_{2} \mathrm{kWh}^{-1}$. The best paddle wheel aerator is the Moore and Boyd's design with SAE value $2.54 \mathrm{~kg} \mathrm{O}_{2} \mathrm{kWh}^{-1}$. Some manufacturers use the basic design of the aerator 2.25-7.5 kW with the SOTR value of 17.4- $23.2 \mathrm{~kg} \mathrm{O}_{2} \mathrm{~h}^{-1}$ and the average SAE value of $2.2 \mathrm{~kg} \mathrm{O}_{2} \mathrm{~kW} \mathrm{~h}^{-1}$ (Moore \& Boyd 1992).

Aeration Principles. Aeration is the addition of air containing oxygen into the water. Aeration can be done with the help of a mechanical device called aerator (Boyd, 1982). Aeration can be done in two ways; the first air is inserted into the water by a spurt (splash aerator) and the second air bubble is released into the water (bubbler aerator). How much and quickly gas (oxygen) is transferred into and out of water depends on equilibrium conditions (saturated concentration) and mass transfer (Boyd, 1998; Lekang, 2007).

According to Lekang (2007) the dissolution of oxygen in water takes place through three stages, the oxygen gas from the air to the surface of the film, then diffuses through the 
surface of the film and finally moves into the water mass. The force of thrust causes oxygen to enter the water which is less saturated where there is difference of oxygen pressure in water and oxygen pressure in the air.

Water circulation. Aeration capability in the form of oxygen addition is the main function of the aerator, in addition, the movement of water generated by the aerator also gives advantages. Water circulation during aeration by moving oxygenated water from the aerator to other parts of the pond, lowering temperature and chemical destruction (Avnimelech, 1992; Romaire, 2007). The motion of water generated by the aerator helps maintain the high efficiency of oxygen displacement because the new oxygenated water is turned away from the aerator and replaced by water with low DO concentration. Moore and Whitis (1999) mentioned aeration by the paddle wheel generating DO uniformity at each water depth in the pond, as well as results found by Rogers and Fast, (1988).

Setiawan (2002) designed a paddle wheel resembling a sculpture pedal of a Taiwanese odor with a length of $214 \mathrm{~cm}$, a width of $200 \mathrm{~cm}$ and a height of $80 \mathrm{~cm}$. This aerator can increase oxygen levels from $5 \mathrm{ppm}$ to saturation limit $(7.5 \mathrm{ppm})$ in just 2 hours with the required power of 980 Watt. Susanti (2003) performed further testing of the paddle wheel by varying the diameter $(600 \mathrm{~mm}, 650 \mathrm{~mm}, 700 \mathrm{~mm})$, rotational speed $(80 \mathrm{rpm}, 98$ $\mathrm{rpm}, 116 \mathrm{rpm})$ and pedal operating depth $(50 \mathrm{~mm}, 100,150 \mathrm{~mm})$. The test results showed the best aeration effect produced by the wheel with a diameter of $700 \mathrm{~mm}$, turn speed of 98 rpm and the dept of pedal operation is 50 and $100 \mathrm{~mm}$.

\section{MATERIALS AND METHODS OF RESEARCH}

This research was conducted in Wet Lab of Polytechnic of Marine and Fishery of Sidoarjo for 15 days (Mustofa, 2008). This study is experimental research by using T-test where the modified of paddle wheel and paddle wheel manufacturer standard as treatment while DO or Dissolve Oxygen, Coverage Area, and splash height are performance parameters of paddle wheels (Mustofa, 2008). The research was designed with 2 (two) different types of paddle wheel which is the treatment of 1 (one) paddle wheel resulted from the development of construction design with a power of $0.37 \mathrm{kwh}^{-1}$ and the treatment of 2 (two) is artificial paddle wheel manufacturer with $0,78 \mathrm{kwh}^{-1}$ power.

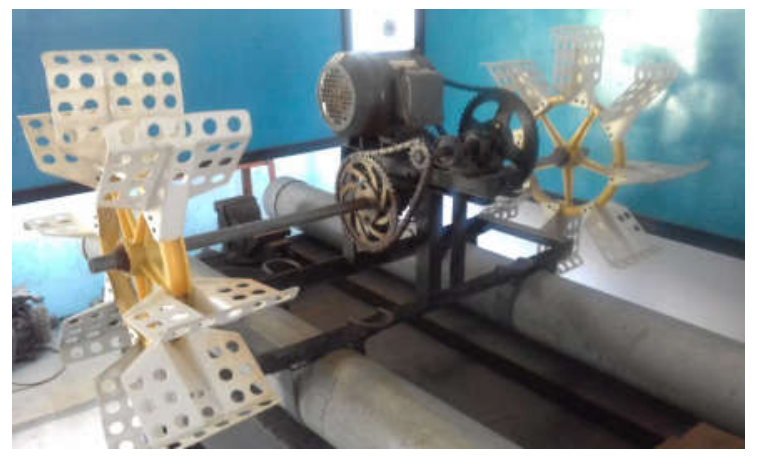

Figure 1 - Modified Paddle Wheel

Measurements of DO (Dissolved Oxygen), Coverage Area, splash height are performed in-situ. To find out the difference of mean value of performance parameter, using T- test (Robert G. D. Steel and James. H. Torrie, 2000). All analysis using SPSS 21 software.

\section{RESULTS AND DISCUSSION}

Endurance Test. Motor endurance test carried out for 15 days (24 hours/day) non-stop. Results of the motor endurance test showed no significant damage to the motor and its supporting components. 
Dissolve of Oxygen. Measurement of Oxygen is done twice a day for 15 days, i.e. at 14:00 to $16: 00 \mathrm{pm}$ and 20:00 to 22:00 pm (BBAT Sukabumi, 2015). Measurements were made to the difference in oxygen content of the waters between 2 hours before the paddle wheel was operated and 2 hours during the operated. The result of measurement to the average value of the increase of oxygen content is the treatment of 1 (Modified paddle wheel $0.5 \mathrm{hp}) 2.56 \mathrm{ppm}$ and the treatment 2 (conventional paddle wheel $1 \mathrm{hp}$ ) $2.54 \mathrm{ppm}$. The result of statistic analysis showed no significant difference between treatments $(p=0,595)$.

This indicates that the performance of the modified paddle wheel against dissolved oxygen increase is similar to that of the conventional paddle wheel of Taiwan. Setiawan (2002) also reported that the Taiwan's paddle wheel with a length of $214 \mathrm{~cm}$, a width of 200 $\mathrm{cm}$ and a height of $80 \mathrm{~cm}$ can increase oxygen levels from $5 \mathrm{ppm}$ to saturation limit $(7.5$ ppm) in just 2 hours with the required power of 980 Watt (1 HP). The result of t- test against the mean value of dissolved oxygen increase in the waters can be seen in the following table.

Table 1 - Dissolved oxygen in the waters

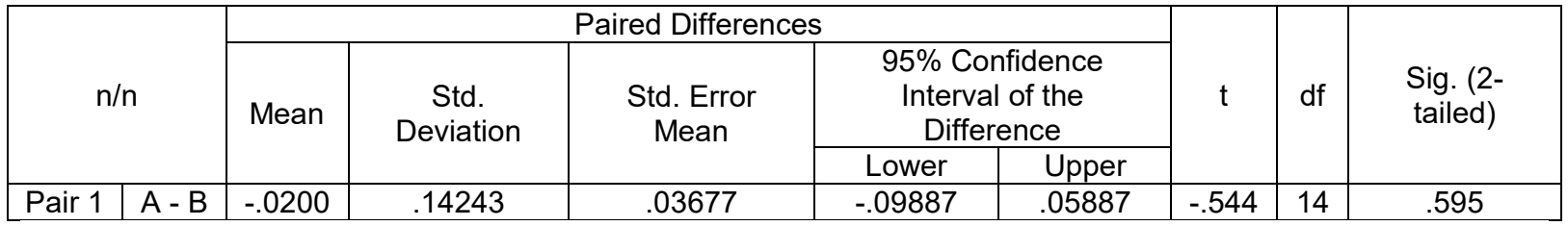

Coverage area. Coverage area is an area that receives flow due to the influence of paddle wheel. The result of the measurement against the mean values treatment 1 (Modified paddle wheel $0.5 \mathrm{hp}$ ) is $419,502.6 \mathrm{~cm}^{2}$ and the treatment 2 (Conventional paddle wheel $1 \mathrm{hp}$ ) is $419983.8 \mathrm{~cm}^{2}$.

Table 2 - Result of T-test

Paddle wheel

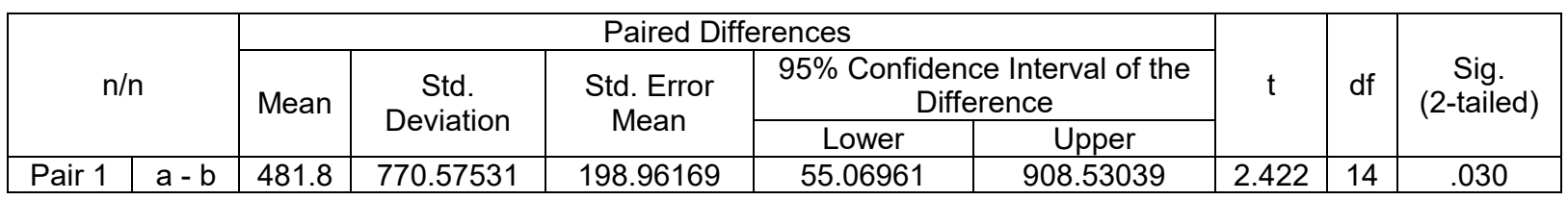

Diameter of burst

\begin{tabular}{|c|c|c|c|c|c|c|c|c|c|}
\hline \multirow{3}{*}{\multicolumn{2}{|c|}{$n / n$}} & \multicolumn{5}{|c|}{ Paired Differences } & \multirow{3}{*}{$\mathrm{t}$} & \multirow{3}{*}{$d f$} & \multirow{3}{*}{$\begin{array}{c}\text { Sig. } \\
\text { (2-tailed) }\end{array}$} \\
\hline & & \multirow[t]{2}{*}{ Mean } & \multirow{2}{*}{$\begin{array}{c}\text { Std. } \\
\text { Deviation }\end{array}$} & \multirow{2}{*}{$\begin{array}{l}\text { Std. Error } \\
\text { Mean }\end{array}$} & \multicolumn{2}{|c|}{$\begin{array}{c}95 \% \text { Confidence Interval of } \\
\text { the Difference }\end{array}$} & & & \\
\hline & & & & & Lower & Upper & & & \\
\hline Pair 1 & $A-B$ & -1.86667 & 4.45400 & 1.15002 & -4.33321 & .59988 & -1.623 & 14 & .127 \\
\hline
\end{tabular}

The result of statistic analysis showed significant different between treatments $(p=$ 0,030 ). This shows that the performance of the modified paddle wheel to the coverage area is better than the performance of the conventional paddle wheel of Taiwan.

High of bursts. The burst height is measured from the water surface on the axle of the paddle wheel to the highest limit of the arch formed by the splashing of the water from the wheel. The result of measuring the average high value of bursts is Treatment $1(0.5 \mathrm{hp}$ modification wheel) $132.2 \mathrm{~cm}$ and treatment 2 (Conventional $1 \mathrm{hp}$ ) $130.2 \mathrm{~cm}$. The result of $\mathrm{t}$ test to mean diameter of burst can be seen in following table.

The result of statistic analysis showed no significant difference between treatments $(p=0,127)$. This shows that the performance of the modified paddle wheel on the high of bursts equal to the performance of the conventional paddle wheel made in Taiwan. 


\section{CONCLUSION AND SUGGESTIONS}

Modified paddle wheel (Treatment 1) can increase DO $=2.56 \mathrm{ppm}$; Coverage area $=419.983,8 \mathrm{~cm}^{2}$; Diameter / height burst $132.2 \mathrm{~cm}$.

Conventional Paddle wheel (treatment 2) can increase DO $=2.54 \mathrm{ppm}$; Coverage area $=418.929,6 \mathrm{~cm}^{2}$; Diameter / height of bursts $130.2 \mathrm{~cm}$.

Result of T- test (Statistical Analysis) against two variables that is DO difference and height of burst show no significant difference between treatments. While the variable of coverage area is significantly different $(p=0.030)$ where the treatment 1 (Modified Paddle wheel with $0.37 \mathrm{kWh}-10,5 \mathrm{hp}$ power is better than treatment 2 (power $0.78 \mathrm{kWh}^{-1} 1 \mathrm{hp}$ ).

Modified paddle wheel with power $0.37 \mathrm{kWh}^{-1} 0,5 \mathrm{hp}$ one phase can be used instead of conventional paddle wheel with power $0.78 \mathrm{kWh}^{-1} 1 \mathrm{hp}$ two phase because it is more efficient in the consumption of electric power that is the efficiency level reaches $0.41 \mathrm{KWh}-1$.

\section{REFERENCES}

1. ASTM Annual Standard Book Composite Material , 1987, ASTM D3039. www.astm.org.

2. Boyd, C. and T. Ahmad. 1987. Evaluation od Aerator for Channel Catfish Farming. Alabama Agr. Exp. Sta., Bull. 584, Auburn University, 52 pp.

3. Braak, K. Van den. 2002. Haemocytic Defence in Black Tiger Shrimp (Panaeus monodon). PhD thesis, Wageningen University - with ref. - with summary in Dutch. Nedherlands. 159 pp.

4. Budiardi, T., Batara, T., dan Wahjuningrum, D. 2005. Tingkat Konsumsi Oksigen Udang Vaname (Litopenaeus vannamei) Dan Model Pengelolaan Oksigen Pada Tambak Intensif. J. Akuakultur Indonesia 4(1):89-96.

5. Callister, W.D. 1994. Materials Scince and Engineering an Introduction. USA: John Wiley and Sons, Inc.

6. Chawla, Krishan K, 1987. Composite Materials, First Edition, Berlin, Springer-Verlag, New York Inc.

7. Fried, R, Joel, 1995. Polymer science and Technology, University of Cincinnati, Prentice Hall, New Jersey, USA.

8. Gunarto dan Hendrajat, E.A. 2008. Budidaya udang vanamei, Litopenaeus vannamei pola semiintensif dengan aplikasi beberapa jenis probiotik komersial. J. Ris. Akuakultur 3(3):339-349.

9. Indra Mawardi, Sumardi, Turmizi, Desain dan Pengembngan Material Kincir Tambak dari Komposit Polimer GFRP, Dosen Jurusan Teknik Mesin Politeknik Negeri Lhokseumawe.

10. Indra, Mawardi, 2004. Studi Sifat Mekanik Komposit Serat Sabut Kelapa dengan Penambahan Batu Apung sebagai Pengisi, Jurnal SAINTEK, ITM. Medan.

11. Indra, Mawardi. 2004. Pemodelan Bentuk Kepala dari Bahan Komposit Polimer dan Responnya Terhadap Beban Impak, Buletin Utama, UISU, Medan.

12. Musthofa Lutfi, Wahyunanto Agung Nugroho, Rizal Dwi Handoko, 2008, Uji Kinerja Aerator Kincir Air Berpenggerak Kincir Angin Savonius Tipe- L Untuk Aerasi Air Tambak, Fakultas Teknologi Pertanian UB.Malang.

13. Tampangallo.B.R, Hidayat Suryanto Suwoyo, dan Early Septiningsih, Pengaruh dang Vannamei (Litopenaeus vannamei) Pada Budidaya Sistem Intensif. Balai Penelitian dan Pengembangan Budidaya Air Payau. Jl. Makmur Dg. Sitakka No. 129, Maros 90512, Sulawesi Selatan. 